\title{
Long-term developments in residues from the processing of alum shale and possible remedies
}

\author{
R. Sjöblom ${ }^{1,2}$ \\ ${ }^{I}$ Waste Science \& Technology, Luleå University of Technology, \\ Sweden \\ ${ }^{2}$ Tekedo $A B$, Sweden
}

\begin{abstract}
In large parts of the world, the gas market has changed dramatically due to the fracking of rock, including shale. It is also anticipated that significant changes will take place in the oil market due to the rapid introduction of the processing of shale for the purpose of oil and gas generation. Many fear that there will be substantial consequences for the environment, especially in the long term. The purpose of the present paper is to share some experiences from related historical activities in Sweden where alum shale has been used for oil extraction, burning of lime, alum production and uranium beneficiation. Legacies exist in terms of shale ash and fines as well as residues from the leaching of uranium, in quantities of a total of tens of millions of tonnes, and at various stages of remediation. The long-term integrity of these residues is analyzed with regard to the possibility of development of acid mine drainage, and in view of the low $\mathrm{Ca}$ and high $\mathrm{S}$ content. It is found that such developments cannot be excluded for the cases in which the alum shale had not been (properly) combusted. Waste materials having appropriately high $\mathrm{pH}$ acid buffering capacities to inhibit acidification are identified together with injection as a promising method of application. The need for mixing on a local scale is discussed together with the possible influence of the injection of slurry on ongoing fires. It is found that further knowledge is needed on a number of issues.

Keywords: shale, alum shale, uranium, shale oil, ash, shale ash, fly ash, remediation, acid drainage, pyrite, waste, injection, legacy, liability, Sweden.
\end{abstract}




\section{Background}

The energy map is being redrawn. According to The Economist [1], gas output in the US has risen by $1 / 3$ since the year 2005 , and oil production by almost the same since the year 2008. New technology - fracking - has led to a decline in the gas price by $2 / 3$ since the year 2008. As a consequence, and if the prices of oil and NLG (Natural Liquid Gas) are high enough, energy companies will drill for these and regard gas as a by-product. In some cases, gas is even being flared.

High expectations exist also on shale oil beneficiation, and this was expressed at the recent Oil Shale Symposium where a ten-fold increase was prognosticated for the next twenty years [2]. The present capacity corresponds to around 30 million tonnes of shale globally.

The beneficiation is to be carried out using in-situ as well as ex-situ methods. The latter type includes the Enefit method developed during decades in Estonia, according to which the crushed shale is first passed through a gigantic rotating retort for pyrolysis, where after the residual shale coke is combusted in a fluidized bed. This process implies that little or no combustible matter is left in the ashes. Such a result and process control may be difficult to achieve using any of the various in situ methods presented [2].

Concerns have been expressed from many sources regarding the environmental impact of fracking as well as shale oil beneficiation. They include the use of chemicals for the fracturing and subsequent extraction, and also for the pyrolysis products. The concerns also include accidents, e. g. unintended "insitu" fires. Not least important is the issue of such long-term developments that might lead to detriment to health and the environment.

Any such impact will depend on the selection of method as well as on how it is being conducted, but also on the shale itself. The chemical composition of shale, including oil shale, shows large variations.

Nonetheless, it appears reasonable to expect that lessons can be learned across the industry, and this includes historical industrial activities.

\section{Analogues and objectives}

\subsection{Analogues}

It has been put forward [3] that "In the eighteenth century Sweden outstripped all other countries in the discovery of new elements. It is blessed with a rich supply of rare ores and, moreover, it had a long succession of brilliant chemists and mineralogists whose greatest delight was to investigate these curious minerals."

These developments occurred in parallel to and as a result of the prosperous activities in the mining industry. However, a high price often had to be paid in terms of detriment to health and the environment.

For instance, the Falun copper mine [4] was in use for much more than a millennium and until recent times, in which process a total of 30 million tonnes of ore may have been removed. It has been estimated that a total of 6.2 million tonnes of sulphur dioxide were emitted, leading to a total deposition of around 
$10 \mathrm{~kg} / \mathrm{m}^{2}$ of sulphur (30 kg/m $\mathrm{m}^{2}$ figured as concentrated sulphuric acid) in the most heavily polluted areas, and around a tenth of this value at a distance of 3 $10 \mathrm{~km}$ from the mine. It was reported that grass and herbs were completely absent near the mine, and there was no moss on the stones within a distance of around $5 \mathrm{~km}$. The tailings contain pyrite $\left(\mathrm{FeS}_{2}\right)$, which weathered, leading to acid mine drainage and spreading of heavy metals. The site has now been remediated.

Pyrite is also one of the major minerals in alum shale, and this together with the near absence of calcium has provided the basis for production of alum $\left(\mathrm{KAl}\left(\mathrm{SO}_{4}\right)_{2}\right)$ that was used e. g. as a mordant for wool. The process relies on conversion of the sulphide to sulphuric acid and the subsequent dissolution of potassium and aluminium.

The alum shale has a content of organic compounds up to around $20 \%$ (the sum of $\mathrm{C}$ and $\mathrm{H}$ in [5]) and has therefore been utilized as a fuel for burning of lime and later for production of oil. During primarily the 1970s, shale was utilised for beneficiation of uranium by leaching with sulphuric acid.

The alum shale in the areas of Närke, Västergötland and Öland (south-central Sweden) has $\mathrm{Si}, \mathrm{Al}$ and $\mathrm{Fe}$ (in oxide form) as the major elements and contain, in addition, around $5-7 \% \mathrm{~S}$ and $<1 \% \mathrm{Ca}$ figured on the shale itself, disregarding limestone lenses that may exist in the rock in some cases $[5,6]$. Hence, the fundamental prerequisites exist for oxidation of sulphur and the subsequent development of acid drainage (see further below).

\subsection{Objectives}

The existence, theoretically, of prerequisites for acid drainage and associated spreading of contaminants raises the questions of whether such effects have been observed as well as of whether they should be expected to take place in the future. Such experience from historical sites may serve as analogues when environmental impact assessments are to be made on virgin sites in conjunction with shale oil production.

The purpose of the present paper is to share such experience. In particular, the following questions are to be illuminated:

- Can acid drainage be excluded?

- If not, can the situation be remediated?

\section{Prerequisites for acidic conditions}

There are many sources in the international literature on acid drainage, and the following is based, in particular, on the excellent compilation in [7]. Important sources for the discussion on the behaviour of iron include [8-10]. Most of the reactions presented below are biotic. This means e. $g$. that there is frequently an incubation time involved during which reactions are slow.

Acid drainage may appear as a result of oxidation of sulphides, in which process sulphuric acid is formed. This acid may dissolve many of the elements, except silicon in an oxide form. Oxides of aluminium and iron-III may also come into solution, although reluctantly and after most of the other elements. Of 
course, in reality, trace elements may be incorporated into acid resistant phases in the form of solid solution and thus not be available to acidic dissolution.

Acid drainage, or as is often the case, acid mine drainage, is a treacherous phenomenon in that the existence of sulphide and availability of oxygen are only necessary but not sufficient prerequisites.

For instance, acidic conditions do not develop when zinc sulphide is being oxidized:

$$
\mathrm{ZnS}+2 \mathrm{O}_{2}<=\mathrm{ZnSO}_{4}
$$

However, such conditions may develop during oxidation of pyrite:

$$
2 \mathrm{FeS}_{2}+7 \mathrm{O}_{2}+6 \mathrm{H}_{2} \mathrm{O}<=>2 \mathrm{Fe}^{2+}+4 \mathrm{SO}_{4}{ }^{2-}+4 \mathrm{H}_{3} \mathrm{O}^{+}
$$

Furthermore, in the presence of atmospheric oxygen, iron may be further oxidized to iron-III according to either of the following reactions:

$$
\begin{gathered}
2 \mathrm{Fe}^{2+}+1 / 2 \mathrm{O}_{2}+2 \mathrm{H}_{3} \mathrm{O}^{+}<=2 \mathrm{Fe}^{3+}+3 \mathrm{H}_{2} \mathrm{O} \\
2 \mathrm{Fe}^{2+}+1 / 2 \mathrm{O}_{2}+9 \mathrm{H}_{2} \mathrm{O}<=>2 \mathrm{Fe}(\mathrm{OH})_{3}(\mathrm{~s})+4 \mathrm{H}_{3} \mathrm{O}^{+}
\end{gathered}
$$

Reaction (3a) takes place under strongly acidic conditions, whilst (3b) takes place when the $\mathrm{pH}$ is higher. Iron-III-hydroxide has a very low solubility under neutral conditions, but the solubility is strongly dependent on ageing, and the equilibrium constant can vary over several orders of magnitude depending on the maturity of the precipitate.

An obvious remedy against acid drainage is thus the exclusion of atmospheric oxygen. However, this is not necessarily sufficient since iron-III might be used by the microorganisms as an oxidant for acid generation.

Iron oxides and hydroxides are well-known sinks for a large number of elements which fit into these structures by means of solid solution. Such effects may lead to a stabilization of various elements comparable to that of the corresponding iron-III(hydr)oxide itself.

Thus, oxidation of pyrite might lead to the development of protective layers of iron-III hydroxides, see Eq. (3b), scavenging various trace elements as well as protecting the pyrite grains against further oxidative attack. However, oxidation might also - depending on the precise conditions - lead to dissolution of the iron(hydr)oxide and an accelerated attack on the remaining pyrite.

Thus, there may be a race between the neutralizing tendencies and the oxidative ones. Among the sulphides, ordinary pyrite $\left(\mathrm{FeS}_{2}\right)$ is known to be comparatively susceptible to oxidation. Similarly, among the possible $\mathrm{pH}$ buffering phases, calcium carbonate is well known to provide prompt buffering. Of course, it helps in this regard that the reactant expelled, carbon dioxide, is a gas that easily dissipates.

The theory described briefly above corresponds quite well to what is observed in practice. A number of cases are mentioned in [7] and the respective $\mathrm{pH}$ values vary from below 1 to around neutral. In practice, presence of a surplus of limestone inhibits acid drainage. Thus, knowledge about the chemistry together with tests on buffer capacity may be utilized in order to assess the potential for acid drainage. In the present paper, with the present alum shale chemistry, the 
atomic ratio of calcium to sulphur will be used for the purpose of identifying cases where a potential for acid drainage might exist.

\section{Historic processes and associated residues}

\subsection{Alum and lime production}

\subsubsection{Alum production}

According to [11], beneficiation of alum from alum shale started in the early 17 th century and ended early in the 20 th century. The contemporary source [12] informs that although fresh alum shale does not contain alum, this substance might be extracted from weathered material. The alum shale was burned together with some wood as well as previously burnt shale. The process took weeks or months, and it was imperative that the temperature was kept low [13]. One type of arrangement for the roasting is shown in Figure 1.

The roasted material was then leached in pools, and the lie was concentrated in vessels of lead by passing hot fumes over the surface of the liquid. Finally, the product alum $\left(\mathrm{KAl}\left(\mathrm{SO}_{4}\right)_{2}\right)$ was obtained by crystallization.

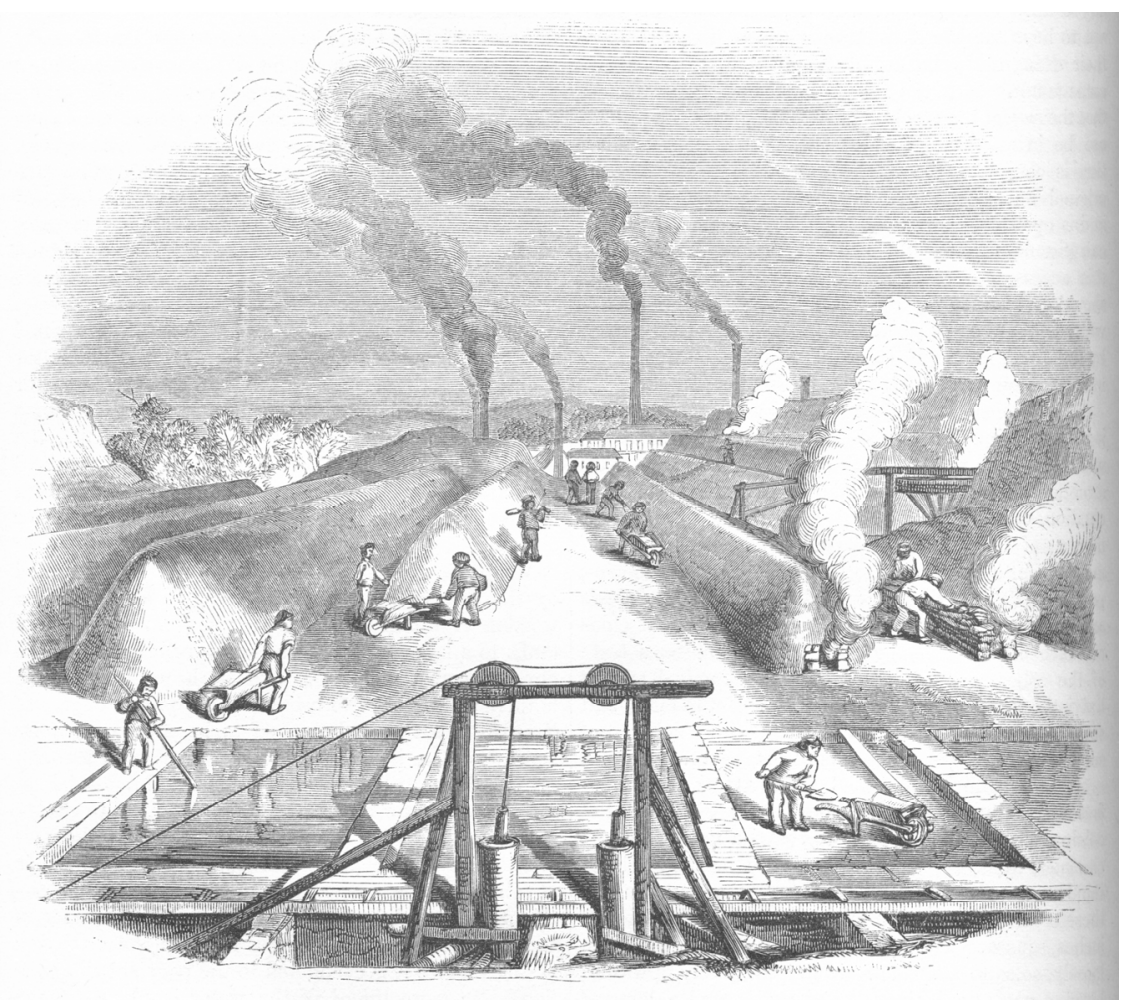

Figure 1: Roasting of shale for the purpose of alum production - pools for leaching in the foreground. (Image taken from [13].) 
The source [11] also explains about the early developments of the direct method for sulphuric acid production, namely by catalytic oxidation of sulphur dioxide at a moderate temperature using e. g. roasted shale as the catalyst.

It is well known in modern chemistry that sulphur trioxide is not stable with regard to disproportioning into sulphur dioxide and oxygen at a high temperature. This confirms the cleverness of maintaining a low temperature during roasting in order for the sulphur to be oxidized to sulphur-VI.

\subsubsection{Lime production}

Initially, and during much of the 18th century, lime burning was carried out using wood $[14,15]$. But later and until around 60 years ago, alum shale was used as fuel in small kilns at the quarries. This was especially feasible in view of the fact that limestone and alum shale in many cases could be mined from adjacent layers of rock.

\subsubsection{Residues from alum and lime production}

Most of the operations on alum and lime production were small and scattered throughout the landscape, and so are the heaps of ash which are easily distinguished due to their characteristic pink colour.

No precise general compilation of these remains has been found, but review of a number of sources indicates that the total amount may be 20-40 million tonnes altogether in south-central Sweden (Närke, Västergötland and Öland).

The chemistries are quite different between alum and lime production residues, although this may not be distinguishable by the naked eye. Alum production residues at Degerhamn on Öland show a pH of around 4 [16], whilst a $\mathrm{pH}$ of 11 has been found in other ash [6]. Obviously, the high $\mathrm{pH}$ value is associated with lime production where the shale ash contains residues from the limestone.

\subsection{Shale oil production}

Production of shale oil according to the Bergh method, see Figure 2, was started in 1925 with an annual capacity of about 500 tonnes of oil [15] corresponding to roughly 10000 tonnes of shale ash. The production was grossly expanded during the second world war, and was maintained at Kvarntorp near Örebro until the year 1966, mainly for the purpose of preparedness in case of a cut-off from import of oil. Actually, a number of different methods were utilized and several different products sold including shale oil, liquid natural gas, electricity, elemental sulphur and ammonia.

With its content of about $18 \%$ organic carbon, $2 \%$ organic hydrogen and $7 \%$ sulphur, and generating only about $5 \%$ oil on pyrolysis [5], the Swedish alum shale is poor in comparison with shale used for oil production elsewhere. Moreover [17], about 30 percent of the content of sulphur was released into the pyrolysis gases in the form of dihydrogen sulfide, and $40 \%$ into the fumes from the combustion of the shale coke in the form of sulphur dioxide. The content of sulphur dioxide in the fumes was $0.7 \%=20 \mathrm{~g} / \mathrm{m}^{3}$. This figure might be 


\begin{tabular}{|c|c|}
\hline$\circ \circ \circ \circ \circ$ & 00000 \\
\hline $0 \circ 000$ & $0 \circ 000$ \\
\hline$\circ \circ \circ \circ \circ$ & $\circ \circ \circ \circ \circ$ \\
\hline$\circ 0000$ & 00000 \\
\hline$\circ \circ \circ \circ \circ$ & $\circ \circ \circ \circ \circ$ \\
\hline$\circ \circ \circ \circ \circ$ & $\circ \circ \circ \circ \circ$ \\
\hline$\circ \circ \circ \circ \circ$ & $\circ \circ \circ \circ \circ$ \\
\hline
\end{tabular}

\section{Arrangement of 70 units in a block}

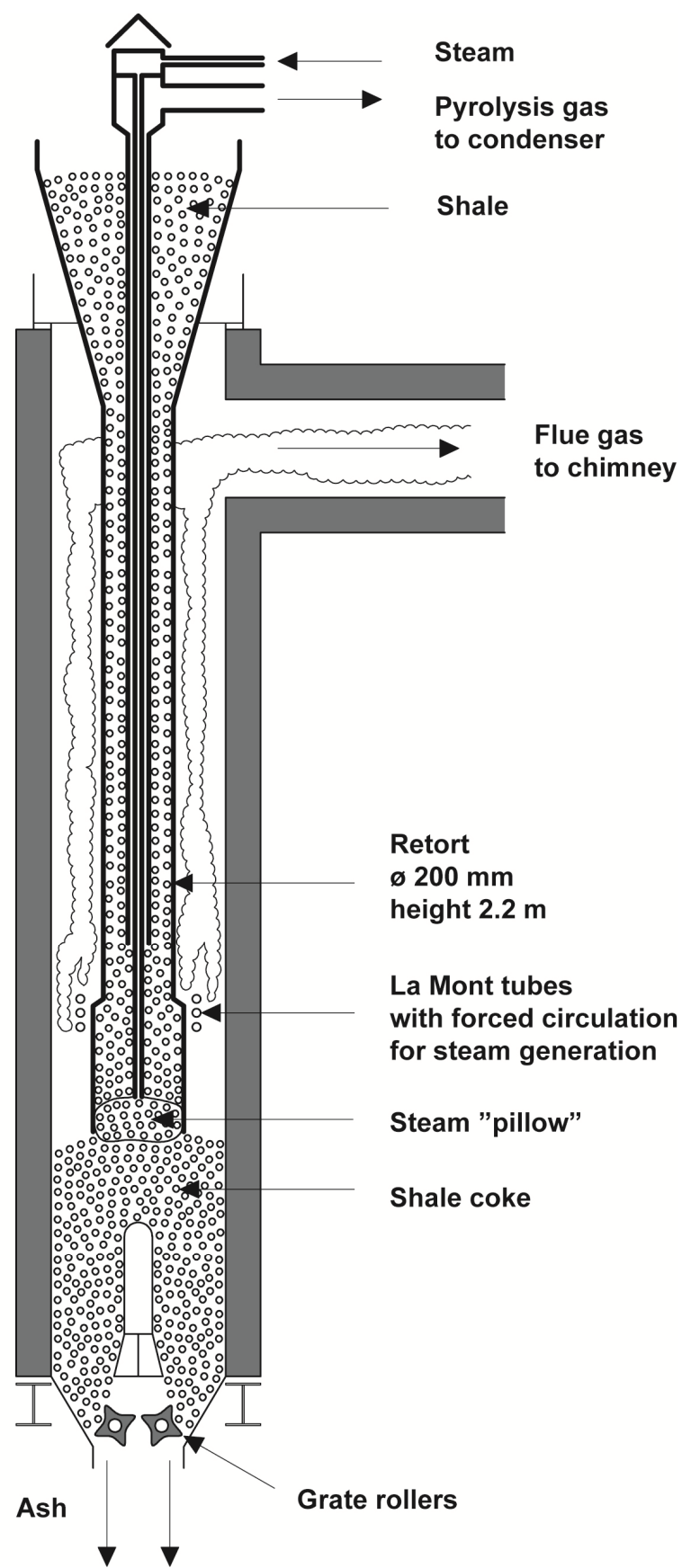

Figure 2: The Bergh system for shale oil production - cross section. (Image redrawn by Fabian Sjöblom after [18].) 
compared with present day emission limits which might be on the order of $0.2 \mathrm{~g} / \mathrm{m}^{3}$ i.e. perhaps around 100 times lower. The annual emission was around 100000 tonnes, figured as sulphur dioxide.

According to [19], a total of 50 million tonnes of rock were mined at Kvarntorp. (Actually this figure includes the production at Kinne-Kleva, but the ash there amounts to less than 0,5 million tonnes.) This figure is consistent with the volume of the shale ash heap at Kvarntorp which has been estimated to 40 million $\mathrm{m}^{3}$ [20] together with the density of 1.1 tonnes per $\mathrm{m}^{3}$ mentioned in [21].

Actually, the rock at the mine contained lenses of limestone (5-10\% of total) which were removed down to $4 \%$ by sorting by hand. But the shale itself contains about $1 \%$ of $\mathrm{Ca}$ figured as $\mathrm{CaO}$, corresponding to $1.8 \%$ figured as calcium carbonate. This works out to a calcium to sulphur ratio of around 0.8 in the ash considering the loss of sulphur during the process. Thus, the ash might not be expected to provide much of a buffer capacity against lowering of the $\mathrm{pH}$.

Moreover [17] only $60 \%$ of the mined material passed through the furnaces, and $30 \%$ comprised fines from the crushing which were rejected and deposited on the same heap as the ash. The process had been optimized for capacity, and therefore the shale coke was ejected from the furnaces before they were completely burned out. They were mostly deposited on the heap in a hot condition.

The heap is still burning and the temperature inside may be up to around 500$700^{\circ} \mathrm{C}$ in some places [20]. The atomic ratio of calcium to sulphur in the fines may only be around 0.3 , and thus the conditions in the burning fines resemble the ideal conditions for acid drainage development achieved with some efforts in conjunction with the production of alum described above.

\subsection{Uranium beneficiation}

Some general information on the early Swedish nuclear activities and the associated environmental liabilities can be found in [22, 23]. These activities include the uranium mining and beneficiation facility at Ranstad near Skövde, which was in operation during 1965-1969 [24, 25], see also [22, 23]. It produced a total of 215 tonnes of uranium, from 1.5 million tonnes of alum shale containing on average $0.03 \%$ uranium. The uranium was beneficiated by leaching with $15 \%$ sulphuric acid together with liquid-liquid extraction.

The residues were accumulated in a heap, and it was soon discovered that the shale weathered and generated acid in the process. It was realized that another method was needed for any future large-scale uranium mining and beneficiation. Thus a new method was developed which included mixing of the residues with limestone powder which stopped the weathering (cf. Section 3). Somewhat later, another method was developed for existing tailings and it involved disposal under a water table.

In the final selection, neither was used, and instead the tailings were simply covered (during 1990-1992) [25, 26] (from bottom to top) with 0.3 metres claymoraine mixture, 0.2 metres of crushed limestone, 1.2 metres of moraine, and 0.2 metres of a soil-moraine mixture. According to [25], the rate of water percolation through this seal is $10-15 \%$ of the precipitation, which with the local 
annual rainfall may correspond to a maximum of around 100 litres per square metre.

It has also been reported that this seal is gas-tight since no oxygen could be determined in the lysimeters [27]. An alternative explanation may be that oxygen had been consumed in the weathering processes in the shale.

Gases exchange much more rapidly than liquids, and durable gas seals in geotechnical constructions are difficult to establish, especially in view of the variations in atmospheric pressure that take place together with the variations in the weather. Data in [27] indicate that the porosity in the tailings is open.

It may also be interesting to note that it was eventually identified [24] that a roasting of the shale at a low temperature, $500-600^{\circ} \mathrm{C}$, might make it possible to leach the uranium (almost) without the addition of any acid. Similar effects might be achieved by just storing crushed shale outdoors in heaps; however, this was not verified on a large scale.

\section{Possible remedies}

\subsection{Materials}

A remedy in terms of a suitable additive has already been mentioned in Section 4.3 above, namely the addition of crushed limestone. But it is not necessary to use virgin materials for such a purpose. Available amounts and absence of contaminants vary with distance. Ashes generated by district heating facilities in Sweden amount to 1.7 million tonnes annually [28]. They vary in quality from very pure ones from biofuels to those classified as hazardous waste. It should be remembered, however, that it may not be the content of potentially hazardous elements that governs the risk to health and the environment, but how such elements are stabilized. Thus, addition of ash may not only provide the $\mathrm{pH}$ buffering needed, but may also lead to stabilization. Of course, such issues will have to be studied in detail before any claims can be made for any particular ash.

Similar ashes may be obtained from the forest industry and they have typically lower levels of "impurities". The steel industry in Sweden generates only relatively small volumes of waste, around 0,3 million tonnes annually, since most of oxide material exiting are by-products, e. g. blast furnace slag that is sold and used as a cement type of material. The waste generated is quite free of "contaminants" and can be assessed to constitute excellent $\mathrm{pH}$ buffering agents.

Large volumes of shale ash, on the order of 20 million tonnes per year, are generated at the Enefit facilities in Estonia. They are generally "cleaner" than the Swedish shale ashes, and have a very high $\mathrm{pH}$ buffering capacity. They are generated quite close to port facilities.

\subsection{Methods}

Mixing a material that is already in place with a remediating agent is, of course, costly, and this might have been governing the decision (cf. Section 4.3 above) not to mix the leached shale with limestone powder. 
There are, however, alternatives to such "conventional" mixing, e. g. processes resembling that used for lime stabilization of soil.

The most promising technique may perhaps be injection. It has been practiced with good results on a full scale on domestic waste [29] and on a "drum scale" on sulphide ore tailings [30], see also [31].

\section{Discussion and conclusions}

The compilation above shows that occurrence of acid drainage cannot generally be excluded in residues of and from alum shale. The situation is highly variable, however, depending on the process used. Residues from lime manufacturing might be "safe" as a result of "contamination" with lime, whilst fines in the Kvarntorp heap might undergo processes very similar to those used for the manufacturing of alum where acid drainage conditions were established deliberately.

In this paper, the method of figuring the atomic ratio of calcium to sulphur has been used. Admittedly, this is a very coarse test, but the lower the ratio (for the same type of material) the higher the potential for future problems.

It should be recognized, that the possibility to remediate may decrease with time. Sulphur dioxide vapour can be absorbed at some distance from where they were generated, and this may help in conjunction with injection. Adding buffering material in time may mean that unprotected surfaces may never develop on the pyrite grains. It may take more than absence of oxygen to prove that there is no gas exchange between residues and the atmosphere.

There is a huge potential for remediation in that suitable material as well as promising methods for application are available.

It is concluded that prompt and resolute action is warranted with regard to the research and technical development needed, as well as on the remediating actions themselves.

Most of the present problems might have been avoided had the residues been mixed with limestone or similar in the first place. Thus, a comprehensive multidisciplinary approach including lessons learned from previous activities should be applied for any related new projects.

\section{Acknowledgements}

The present work has - directly or indirectly - been supported by the following organizations: [The Swedish] Thermal Engineering Research Institute (Värmeforsk), the Swedish Waste Management (Avfall Sverige), Svenska Energiaskor $A B$ (which translates to: "Swedish Energy Ashes Inc.") and Angpanneföreningen's Foundation for Research and Development (Ångpanneföreningens Forskningsstiftelse). 


\section{References}

[1] From sunset to new dawn. The Economist. November 16th, 2013.

[2] Boak, J., Where? How Soon? How Much? How Risky? International Oil Shale Symposium. Tallinn, Estonia, June 10-13, 2013.

[3] Weeks, M. E., Discovery of the elements, 6th edition. Journal of chemical education, second printing, 1960.

[4] Lindeström, L., The environmental history of the Falun Mine. Almqvist \& Wiksell Tryckeri, Uppsala 2003.

[5] Gejrot, C. \& Schjånberg, E., The Shale oil industry in Sweden. The 4th World Petroleum Congress, June 6-15, 1955, Rome, Italy.

[6] Arvidson, O. \& Lind, B., Environmental assessment of alum shale ash in the county of Västra Götaland (In Swedish: Miljöbedömning av rödfyr Västra Götalands Län). Swedish Geotechnical Institute, February, 2004.

[7] Callender, E., Heavy Metals in the environment - historical trends. In Lollar B S, editor. Environmental geochemistry. Elsevier 2005.

[8] Blowes, D. W., Ptacek, C. J. and Jambor, J. L., \& Weisner, C. G., The geochemistry of acid mine drainage. In Lollar, B. S., editor. Environmental geochemistry. Treatise on geochemistry, Volume 9. Elsevier 2005.

[9] Cornell, R. M. \& Schwertmann, U., The iron oxides. Structure, properties, reactions, occurrences and uses. Wiley-VCH, 2003.

[10] Sjöblom, R. \& Noläng, B., On the significance of solid solution in iron (hydr)oxides for immobilisation of potentially polluting elements in ashes. Värmeforsk, Ash Utilisation 2012, January 25-27, 2012, Stockholm, Sweden.

[11] Larsson, A., The chemical industry in Sweden. (In Swedish: Den svenska kemiska industrin). Aktiebolaget Hasse W. Tullbergs Förlag, Stockholm 1922.

[12] Scheffer, H. T., Chemical lectures. (In Swedish: Chemiske föreläsningar). Uppsala, 1775. The lectures were actually held at around 1750.

[13] Muspratt, J. S., Chemistry, Theoretical, Practical and Analytical as applied and relating to the Arts and Manufactures. Published by William Mackenzie, Glasgow at around 1860.

[14] Linné, C., Travel to Westgothia. (In Swedish: Wästgötaresa.) Stockholm 1747.

[15] Bergh, S., From the records of the Swedish oil shale. (In Swedish: Ur den svenska oljeskifferns hävder). In Dædalus, Tekniska museets årsbok, årgång 64, 1966 (title: Filmen 100 år).

[16] Lavergren, U., Metal dispersion from natural and processed black shale. Doctoral dissertation, Dissertation series, No. 57. University of Kalmar, 2008.

[17] The shale oil question. (In Swedish: Skifferoljefrågan). SOU 1961:27, Stockholm, 1961. A public investigation issued by the Swedish Government. 
[18] Swedish Shale oil, production methods in Sweden. OECD Documentation, Technical Assistance Mission No 93, Paris, 1952.

[19] Dyni, J. R., Geology and resources of some world oil-shale deposits. U. S. Geological Survey Scientific investigations Report 2005-5294. June, 2006.

[20] Holm, T., The Kvarntorp area - a study of the Kvarntorp heap (In Swedish: Kvarntorpsområdet, Studie av kvarntorpshögen). SWECO VIAK AB, Prestudy, Gothenburg, June 2nd, 2005.

[21] Holmström, H. \& Eriksson, H., Mass balances and mechanisms for migration. (In Swedish: Massbalanser och spridningsmekanismer.) Project Degerhamn, Report 2005:07. University of Kalmar, Sweden, 2005.

[22] Sjöblom, R. \& Lindskog, S., Management of intergenerational environmental liabilities - example of decommissioning of nuclear research and development facilities. International Journal of Sustainable Development \& Planning, Vol. 7, No. 2, pp 135-158, 2012.

[23] Sjöblom, R., Lindskog, S. \& Andreas, L., Long term aspects of landfilling and surface disposal: lessons learned from nuclear and non-nuclear decommissioning, remediation and waste management. Journal of Earth Sciences and Geotechnical Engineering, vol. 3, no. 3, pp 33-51, 2013.

[24] Strandell, E. editor, Uranium from shale, the Ranstad plant. (In Swedish: Uran ur skiffer, Ranstadverket). Printing financed by AB SVAFO, 1998.

[25] Sundblad, B., 1998. Remediation of the former uranium mine at Ranstad. In Rofer, C. K. \& Kaasik, T., editors, 1998. NATO Science Series. 1. Disarmament Technologies - Vol 28. Proceedings of the NATO Advanced Research Workshop on Turning a problem into a resource: Remediation and waste management at the Sillamäe site, Estonia, 5-9 October, 1998.

[26] Hultgren, Å. \& Olsson, G., 1993. Uranium recovery in Sweden, history and perspective. SKB Arbetsrapport 93-42. Swedish Nuclear Fuel and Waste Management Company.

[27] Sternbeck, J., Arnér, M. \& Berzell, A., Ranstad: Assessment of health and environment impact at Tranebärssjön and the leach test area. (In Swedish: Ranstad: miljö- och hälsoriskbedömning av Tranebärssjön och lakrestområdet). AB SVAFO, April, 2005.

[28] Ashes in Sweden 2012. (In Swedish: Askor i Sverige 2012). Svenska Energiaskor, 2012.

[29] Andreas, L., Wikman, K., Berg, M., Sjöblom, R. \& Lagerkvist, A., Ash injection for landfill stabilisation. Ninth international waste management and landfill symposium, 6-10 October, 2003, s. 12. Margherita di Pula (Cagliari), Sardinia, Italy.

[30] Sartz, L. \& Bäckström, M., Fly ash for stabilization of historic mine waste deposits. Värmeforsk, Ash Utilisation 2012, January 25-27, 2012, Stockholm, Sweden.

[31] Sartz, L., Alkaline by-products as amendments for remediation of historic mine sites. Doctoral thesis. Örebro University, 2010. 